\title{
Evidence of Trichodesmium viral lysis and potential significance for biogeochemical cycling in the oligotrophic ocean
}

\author{
Ian Hewson ${ }^{1, *}$, Sarah R. Govil ${ }^{2}$, Douglas G. Capone ${ }^{1}$, Edward J. Carpenter ${ }^{2}$, \\ Jed A. Fuhrman ${ }^{1}$ \\ ${ }^{1}$ Department of Biological Sciences, University of Southern California, 3616 Trousdale Parkway, AHF 107, Los Angeles, \\ California 90089-0371, USA \\ ${ }^{2}$ Romberg Tiburon Center, San Francisco State University, 3152 Paradise Drive, Tiburon, California 94920, USA
}

\begin{abstract}
The planktonic cyanobacterium Trichodesmium spp. is a globally important diazotroph, fixing at least $80 \mathrm{Tg} \mathrm{N} \mathrm{yr}^{-1}$ in tropical waters. Despite its biogeochemical importance, the mechanisms of Trichodesmium mortality, and the means by which its fixed $\mathrm{N}$ enters upper levels of the food web, are poorly understood. Potential virus-like particle (VLP) production by Trichodesmium spp. was observed in both culture (IMS101) and field samples from the tropical North Pacific Ocean, in oceanic waters around the Hawaiian Islands. VLP observed by TEM in IMS101 lysate were approximately $56 \mathrm{~nm}$ wide and untailed, and VLP with similar morphology were observed in tissue treated with mitomycin C. A most-probable number cultivation technique (utilizing bacterized cultures of Trichodesmium) detected moderate abundances of Trichodesmium-infecting cyanophage (605 to $9750 \mathrm{ml}^{-1}$ infecting only 1 cultured strain) in $0.2 \mu \mathrm{m}$-filtered seawater samples from surface, subsurface and deep chlorophyll maximum samples. Estimation of mortality from virus production was not possible due to rapid VLP release in the first $6 \mathrm{~h}$ of dilution incubations. Rather, an indirect approach using burst size (determined from mitomycin $\mathrm{C}$ treatment of washed trichomes resuspended in virus-free seawater), decay rate of VLP (from latter part of virus production incubations) and average cyanophage titer was used to estimate mortality. These conservative calculations suggested that 0.3 to $6.5 \% \mathrm{~d}^{-1}$ (mean $=1.65 \pm 0.99 \% \mathrm{~d}^{-1}$ ) of trichomes could potentially be lysed by viruses, representing the release of approximately 3 to $64 \%$ fixed $\mathrm{N} \mathrm{d}^{-1}$. These estimates are based upon a steady-state maintenance of observed VLP abundance, which in nature could be from lysogeny, pseudolysogeny, carrier state, or successive lytic infection. Viral lysis therefore may represent a significant novel mechanism of $\mathrm{N}$ release from Trichodesmium spp., even in non-bloom conditions.
\end{abstract}

KEY WORDS: Trichodesmium $\cdot$ Cyanophage $\cdot$ Nitrogen $\cdot$ Diazotroph $\cdot$ Lysogeny

\section{INTRODUCTION}

Trichodesmium spp. are an important component of the planktonic flora of the oligotrophic ocean. They occur as colonies and free trichomes, which can account for a large fraction of algal chlorophyll in the upper water column and can form dense accumulations on the surface (up to 1000 colonies $\mathrm{l}^{-1}$ ) (Capone et al. 1997). Moreover, they are diazotrophic, fixing $\mathrm{N}_{2}$ into $\mathrm{NH}_{4}{ }^{+}$and organic $\mathrm{N}$, which may be subsequently released and taken up by surrounding microorganisms in the putatively N-limited ecosystems in which they occur (reviewed in Capone et al. 1997). Virus-like particles (VLP) have been previously observed in cells of Trichodesmium spp. in both culture (NIBB1067) and decaying bloom field samples collected from Carrie Bow Bay, Belize, and viral lysis was induced by the addition of mitomycin $\mathrm{C}$, indicating temperate phage 
had lysogenized Trichodesmium spp. (Ohki 1999). However, to date there have been no previous reports of the potential Trichodesmium spp. mortality rate caused by viral lysis. Temperate cyanophage have been previously documented in several filamentous cyanobacterial genera (Ohki \& Fujita 1996, Hewson et al. 2001), and temperate cyanophage of unicellular cyanobacteria have attracted considerable attention (for review see Suttle 2000). Virus-mediated release of intracellular DOM occurs in bacteria and cyanobacteria (Middelboe \& Lyck 2002), and models indicate greater community productivity in virus-infected compared to uninfected food webs (Fuhrman \& Suttle 1993). Extracellular release of a large fraction of recently fixed $\mathrm{N}$ has been observed in natural samples (Capone et al. 1994, Glibert \& Bronk 1994, Glibert \& O'Neil 1999), which suggests that cell lysis from a process like cyanophage infection of Trichodesmium spp. may be common.

Trichodesmium spp. are not grazed by predominant calanoid or cyclopoid copepods of the water column because of toxins which act as grazing deterrents (Hawser et al. 1992). Certain harpactacoids are able to graze Trichodesmium spp. (Roman 1978, O'Neil \& Roman 1994, O'Neil et al. 1996); however, their populations are generally insufficient to have a major grazing impact. Thus, apoptosis (Wolfe et al. 2003) and particularly viral lysis may be under-appreciated sources of mortality.

Here, VLP production by Trichodesmium spp. was estimated in culture (IMS101) and from field samples collected in the North Pacific Ocean near the Hawaiian archipelago (Fig. 1). Viral mortality of Trichodesmium spp. cannot be measured directly; therefore an indirect approach was used. Mortality was calculated by the number of cyanobacteria that need to be lysed in order to replace VLP lost by decay (assuming steady-state of cyanophage abundance). We estimated burst size by the addition of mitomycin C (Jiang \& Paul 1994, Weinbauer \& Suttle 1996) and a modified dilution technique (Hewson et al. 2001), decay rate by decrease in VLP abundance in the diluted incubations, and ambient cyanophage abundance by most-probable number (MPN) dilution culture (Suttle \& Chan 1993).

\section{MATERIALS AND METHODS}

Burst size and decay rate estimation. Burst size of trichomes was estimated by VLP abundance increase in initially virus-free culture media or seawater containing Trichodesmium spp. (Hewson et al. 2001) and dividing this increase by the total number of trichomes lost in incubations. Trichodesmium spp. colonies and free filaments were collected from surface waters using a $202 \mu \mathrm{m}$ mesh plankton net aboard the RV 'Kilo Moana' in September 2002 (Fig. 1). Colonies were picked from the plankton tow immediately after collection into $20 \mathrm{ml}$ of $\mathrm{GF} / \mathrm{F}$ (Whatman; nominal pore size $0.7 \mathrm{~mm}$ ) filtered seawater from the same site using polycarbonate inoculating loops. An attempt was made to remove attached bacteria by first washing colonies with $\sim 200 \mathrm{ml}$ virus-free $(0.02 \mu \mathrm{m}$ filtered) seawater over a $47 \mathrm{~mm}, 8 \mu \mathrm{m}$ pore size polycarbonate filter. Trichomes were never dried on filter, and were always suspended in a small volume of virus-free seawater during the washing process. Washed trichomes were resuspended in $50 \mathrm{ml}$ virus-free seawater and transferred to an acid-washed and seawater-rinsed polycarbonate $60 \mathrm{ml}$ bottle. Subsamples $(10 \mathrm{ml})$ were withdrawn from incubations after 0, 6, 12 and $24 \mathrm{~h}$ and were preserved with $2 \%, 0.02 \mu \mathrm{m}$ filtered formalin. At several stations, mitomycin $\mathrm{C}\left(0.8 \mathrm{ng} \mathrm{ml}^{-1}\right.$, final concentration) was also added to washed trichome incubations, and samples were withdrawn at 0 and $24 \mathrm{~h}$ for virus enumeration. Preserved samples were processed for VLP and bacterial enumeration via SYBR Green I microscopy (Noble \& Fuhrman 1998) within 24 h of collection. Sample volumes of 0.1 to $2.0 \mathrm{ml}$ were used in

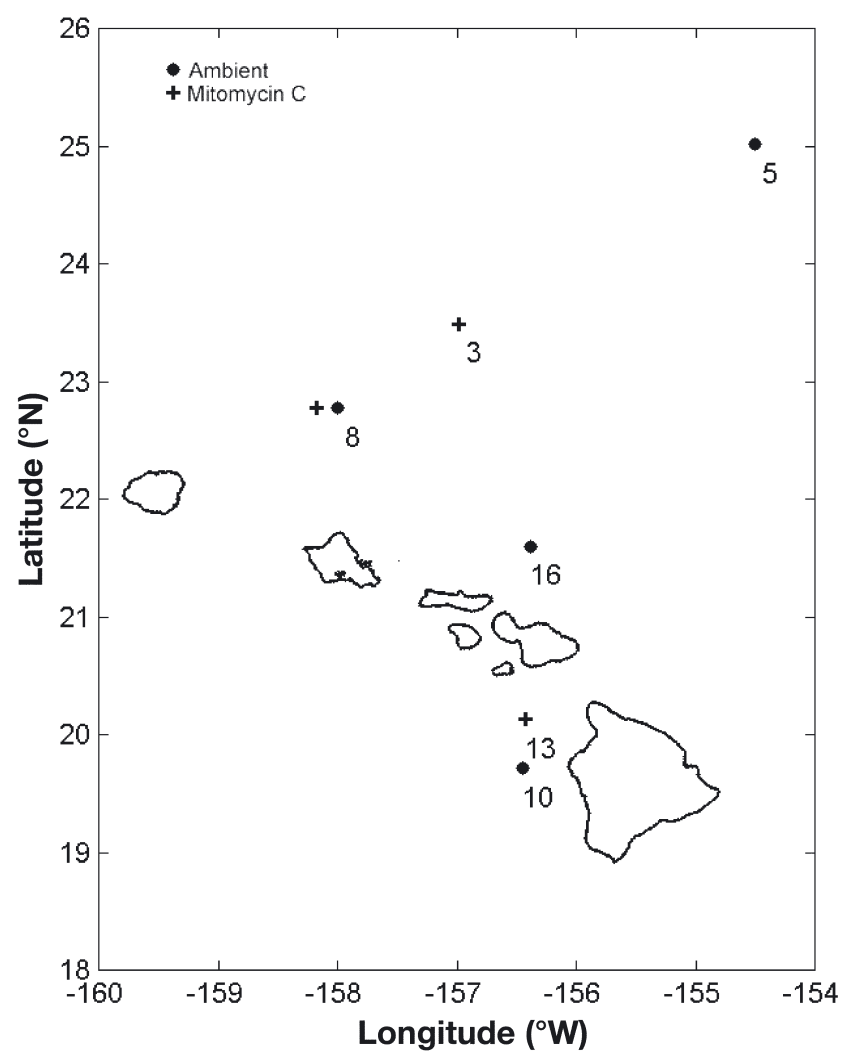

Fig. 1. Stations sampled from the RV 'Kilo Moana' in September 2002 for ambient (•) and mitomycin C included (+) virus production 
slide preparations and more than 200 VLP and bacteria were counted for each sample. Potential VLP production rates were calculated from linear regressions of the initial virus increase (i.e. within the first $6 \mathrm{~h}$ of incubations). Trichome burst size was calculated by subtracting an estimate of the number of viruses produced by heterotrophic bacteria in the incubations as follows: the abundance of heterotrophic bacteria was multiplied by 50 viruses/bacterium (Heldal \& Bratbak 1991) and then by $5 \%$, which assumes that $20 \%$ of heterotrophic bacteria were infected (Suttle 1994) and lysed per day (i.e. lysis of heterotrophic bacteria in the first $6 \mathrm{~h}$ of incubation). Decay rates of viruses were calculated from the rate of decrease in VLP abundance in the final $18 \mathrm{~h}$ of the VLP production experiments.

Transmission electron microscopy. The mitomycin C-induced lysate of washed IMS101 culture, and separate samples from the North Pacific Ocean $\left(20^{\circ} 15^{\prime} \mathrm{N}\right.$, $159^{\circ} 11^{\prime} \mathrm{W}$ ) containing approximately 50 colonies each of Trichodesmium erythraeum and T. thiebautii phenotypes in virus-free water were collected and filtered over $0.2 \mathrm{~mm}$ Durapore filters to remove most cell debris. Filtered lysates $(10 \mathrm{ml})$ were then spotted onto formvar-coated 200-mesh copper electron microscope grids and air dried. Grids were then desalted in sterile deionized $\mathrm{H}_{2} \mathrm{O}$, and negatively stained for $30 \mathrm{~s}$ in $0.5 \%$ uranyl acetate. Samples were examined using a JEOL 1010 transmission electron microscope (TEM) under $200 \mathrm{kV}$ accelerating voltage and $100000 \times$ magnification.

Thin sections of Trichodesmium treated for $24 \mathrm{~h}$ with mitomycin-C were also prepared for electron microscopy to confirm VLP presence in trichomes. The Trichodesmium was fixed in $2 \%$ EM-grade glutaraldehyde (Ted Pella) for $1 \mathrm{~h}$, then centrifuged at $3000 \times g$ for $10 \mathrm{~min}$ to pellet Trichodesmium cells. The pellet was then resuspended in $500 \mathrm{ml}$ Karnovski Buffer (2\% paraformaldehyde and $2.5 \%$ glutaraldehyde) for $48 \mathrm{~h}$. The resuspended Trichodesmium was washed 3 times with $0.2 \mathrm{M}$ cacodylate buffer, before staining with $\mathrm{OsO}_{4}(1 \% \mathrm{v} / \mathrm{v})$ for $10 \mathrm{~min}$. The stained Trichodesmium was washed 2 further times with cacodylate buffer. Samples were then dehydrated in an increasing series of ethanol (30 to $100 \%$ ) before being embedded in SPUR resin (TAAB Laboratories). The embedded Trichodesmium was thin-sectioned into $50 \mathrm{~nm}$ thick slices and sections placed onto formvar-coated 200-mesh copper grids before post-staining with $0.5 \%$ uranyl acetate and $3.2 \%$ lead citrate, and viewing by TEM.

Trichodesmium cyanophage abundance. To determine the ambient abundance of cyanophage of Trichodesmium spp., we assayed seawater from the surface, 20 and $100 \mathrm{~m}$ depth at 2 North Pacific stations using MPN analysis (Suttle \& Chan 1993), at 2 sites where Trichodesmium biomass was high (surface abundances of 100 to 400 trichomes $\mathrm{l}^{-1}$ ) and thus high abundances of cyanophage were expected. Seawater from the target depths was collected in a Niskin bottle array and withdrawn into acid-washed, $50 \mathrm{ml}$ polypropylene centrifuge tubes. The seawater was then syringe-filtered through $0.2 \mu \mathrm{m}$ Acrodiscs (Pall Gelman) into sterile $15 \mathrm{ml}$ polypropylene tubes, to remove most heterotrophic bacteria and particles. Dilutions of the $0.2 \mu \mathrm{m}$ filtered seawater were serially added to exponentially growing bacterized (i.e. containing bacteria) batch culture Trichodesmium sp. IMS101 $\left(\sim 0.2 \mathrm{~d}^{-1}\right.$, Prufert-Bebout et al. 1993) in 96-well polystyrene microtiter plates (12 dilutions total, 8 replicates), and after $7 \mathrm{~d}$, cultures were scored visually for presence/ absence of Trichodesmium spp. Negative controls were wells to which no filtrate was added.

Calculation of Trichodesmium mortality rates. We are able to estimate mortality from viral lysis, because we can calculate the lysis rate necessary to maintain the observed abundance of cyanophage, assuming steady state of cyanophage abundance and the observed viral decay rate. To estimate Trichodesmium spp. mortality rates, the average number of cyanophage was first divided by the burst size of the cyanobacterium (which was in turn calculated from the total abundance increase in VLP at maximum abundance in media or seawater divided by total number of trichome loss), and this was multiplied by average VLP decay rates.

\section{RESULTS AND DISCUSSION}

\section{Burst size and decay rate estimation}

VLP production in incubations was consistently nonlinear over $24 \mathrm{~h}$, with large increases in VLP abundance after $6 \mathrm{~h}$ of containment, followed by decreases in VLP abundance during the remainder of the incubation (Fig. 2). We interpreted this initial VLP production rate to be lysogenic induction of Trichodesmium spp. triggered by collection or washing of trichomes. This was unexpected considering the slow growth rate of the Trichodesmium; however, the presence of VLP in TEM samples of lysate and in thin sections of Trichodesmium supports this conclusion. It is not clear which factors cause lysogenic induction within our incubations of Trichodesmium spp., but in previous studies exposure to ultraviolet radiation, environmental contaminants, and significant changes in cell growth rate have been proposed as mechanisms for viral induction (reviewed in Fuhrman 1999).

Trichodesmium spp. is typically associated with a large number of heterotrophic bacteria and microalgae (Sheridan et al. 2002). We considered the possibility 


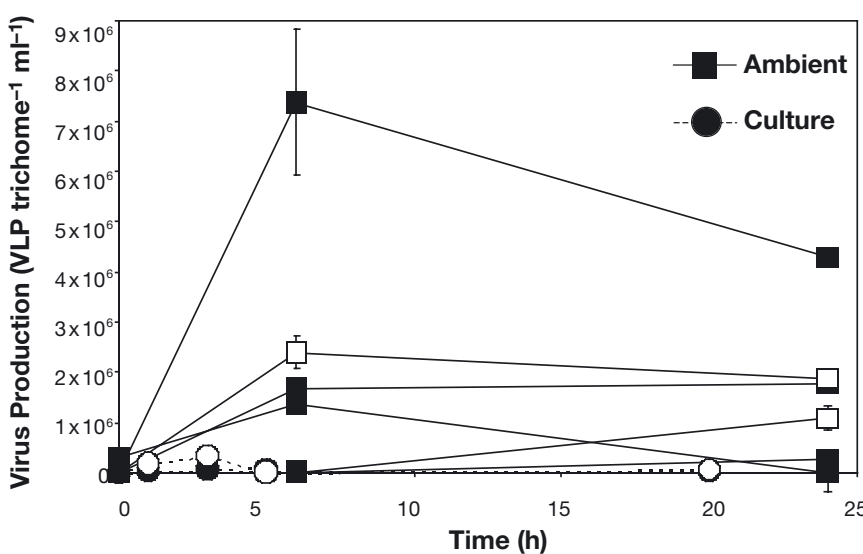

Fig. 2. Virus production by Trichodesmium in both culture (IMS101) and ambient communities. The large increase in virus abundance is presumably due to lysogenic induction from Trichodesmium trichomes, triggered by containment. Heterotrophic bacteria increased in all incubations, possibly due to the release of large amounts if intracellular DOM. Decay rates of viruses were calculated from the decrease in virus abundance in the last $18 \mathrm{~h}$ of the incubations. Light incubations are indicated by open symbols; dark incubations are indicated by closed symbols. Error bars $= \pm \mathrm{SE}$

that the induction was of bacteria other than Trichodesmium in the cultures. Bacterial and VLP abundances at the beginning of assays were low (4 to $15 \times$ $10^{4}$ bacteria $\mathrm{ml}^{-1}$ and 1 to $8 \times 10^{5} \mathrm{VLP}$ $\mathrm{ml}^{-1}$ ), and while they increased during the incubation, their production of viruses could not account for all VLP produced in incubations. If all VLP production resulted from heterotrophic bacterial infection, we calculated that the burst size would have to be $3.9 \times 10^{2}$ to $1.2 \times 10^{4}$ cell $^{-1}$, which is much larger than most recorded burst sizes (Wommack \& Colwell 2000). Still, the bacteria might have accounted for some virus production, so to correct for possible viral production by bacteria, production and decay rates were corrected for by subtracting from VLP abundances, the multiple of bacterial abundance and 0.41 , which assumes $0.83 \%$ of heterotrophic bacteria lyse per hour (Suttle 1994) and that the burst size of bacteria was approximately 50 viruses per cell (Heldal \& Bratbak 1991).

Microscopic examination revealed a large number of VLP originating from the trichomes (Fig. 3). Several incubations were also treated with mitomycin $\mathrm{C}\left(0.8 \mathrm{ng} \mathrm{ml}^{-1}\right)$ in an attempt to induce lysogens. VLP production in controls $\left(6.4 \times 10^{3}\right.$ to $2.9 \times 10^{5}$ VLP trichome ${ }^{-1} \mathrm{~h}^{-1}$ in the first $\left.6 \mathrm{~h}\right)$ were statistically indistinguishable from those with mitomycin $\mathrm{C}$ addition $\left(1.6 \times 10^{4}\right.$ to $3.8 \times 10^{4}$ VLP trichome $\mathrm{e}^{-1} \mathrm{~h}^{-1}$ in the first $6 \mathrm{~h}$; paired $t$-test, $\mathrm{p}=0.24, \mathrm{n}=$ 3). Unwashed IMS101 cultures do not lyse spontaneously over several months of observation (data not shown). Since mitomycin $\mathrm{C}$ addition has been shown to induce lysogens in other studies (Jiang \& Paul 1994), the similar results with and without mitomycin C suggest that VLP production observed in unamended samples could be due to either lysogenic induction or advanced lytic infection.

We observed no relationship between trichomenormalised VLP production and ambient trichome abundance, which suggested that VLP production was independent of trichome concentration. A previous study (McDaniel et al. 2002) has indicated that induction of cyanophage follows a seasonal pattern, with a greater proportion of lysogenic Synechococcus in winter when their abundance was low. Since the calculated contact rate of viruses to trichomes is very low $\left(1.8 \times 10^{4}\right.$ VLP d ${ }^{-1}$ to each trichome based upon contact rate equations in Murray \& Jackson 1992), approximately $5 \times 10^{3}$ trichomes $\mathrm{ml}^{-1}$ (average concentration) are required to propagate successful infection. Within 'tuft' colonies trichome abundance can exceed $10^{7} \mathrm{ml}^{-1}$, and thus virus infection could proceed easily within colonies.

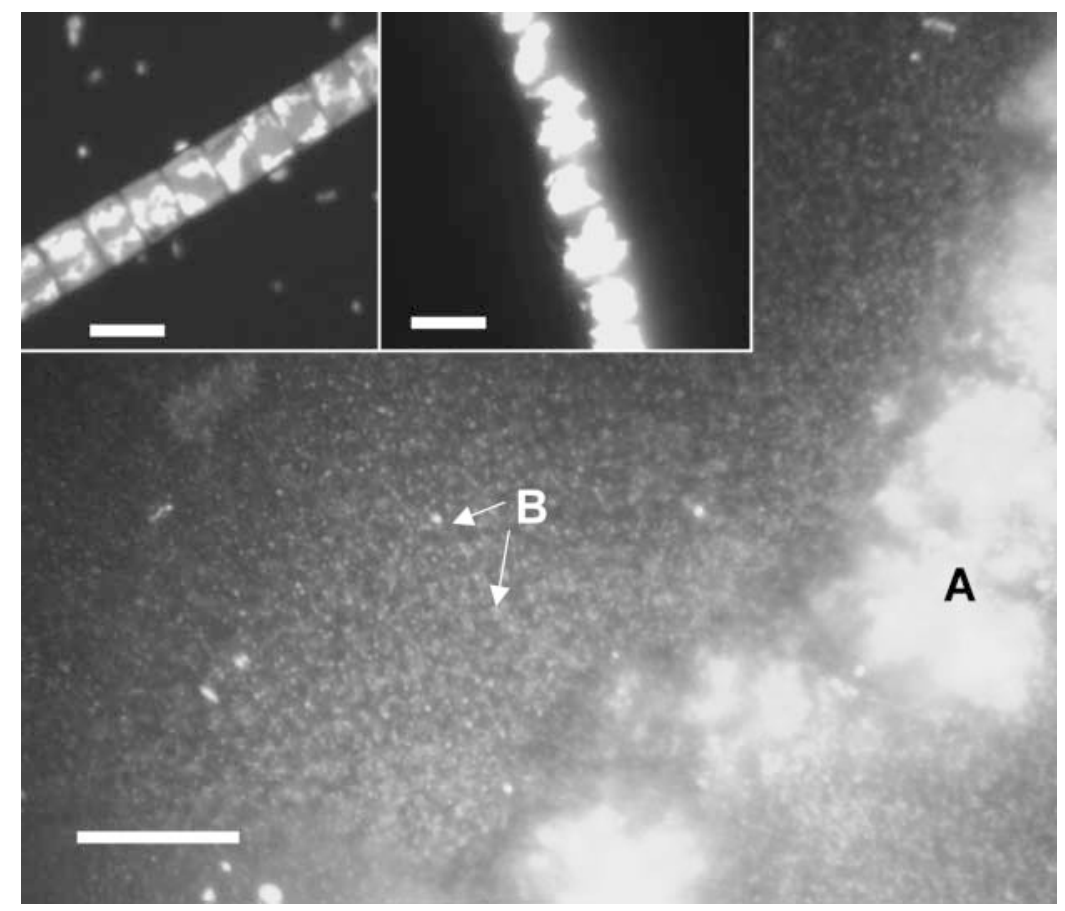

Fig. 3. Photomicrograph of Trichodesmium after addition of mitomycin C demonstratimg VLP production. A: decomposing trichome; B: virus-like particles emanating from trichome. Inset on left shows an unlysed trichome for comparison, and on right a mechanically lysed trichome (squashed beneath a coverslip) demonstrating difference to viral lysis. Scale bars $=20 \mu \mathrm{m}$ 
Assuming all VLP produced by Trichodesmium spp. were freed from trichomes, VLP decay rates were approximately $1.1 \pm 0.2 \% \mathrm{~h}^{-1}$ in natural samples (mean \pm SE of incubations where decay was measurable) and $4.4 \pm 0.6 \% \mathrm{~h}^{-1}$ in culture. This is consistent with virioplankton decay rates in the pelagic ocean (Noble \& Fuhrman 1997).

\section{TEM of Trichodesmium cells and lysates}

We have several reasons to believe that the VLP observed in incubations are viruses of Trichodesmium. Microscopy of lysed trichomes showed a large number of VLP emanating from trichomes (Fig. 3), which is consistent with the large number of VLP released into production incubations. VLP observed by TEM from IMS101 culture lysates were approximately $50 \mathrm{~nm}$ wide, and were electron dense at the center (Fig. 4). Lysates from field samples of Trichodesmium erythraeum contained VLP of a similar size, but lysates of T. thiebautii had notably larger VLP (70 to $100 \mathrm{~nm}$ ). Morphologically similar particles, although notably smaller (26 to $40 \mathrm{~nm}$ ), were observed in thin sections of Trichodesmium treated with mitomycin C after $24 \mathrm{~h}$, while Trichodesmium with no mitomycin $\mathrm{C}$ treatment had no VLP (Fig. 5). The smaller size of VLP observed in thin sections of mitomycin C treated IMS101 could be an artifact of sample preparation and dehydration (thin sectioned healthy cells were collapsed by 2 to $5 \mathrm{~mm}$ between septa in trichome, indicating that shrinkage may have occurred), or may indicate that more than one phenotype of virus is present within Trichodesmium. Interestingly, VLP observed in this study were similar to those documented in Trichodesmium strain NIBB1067 (Ohki 1999).

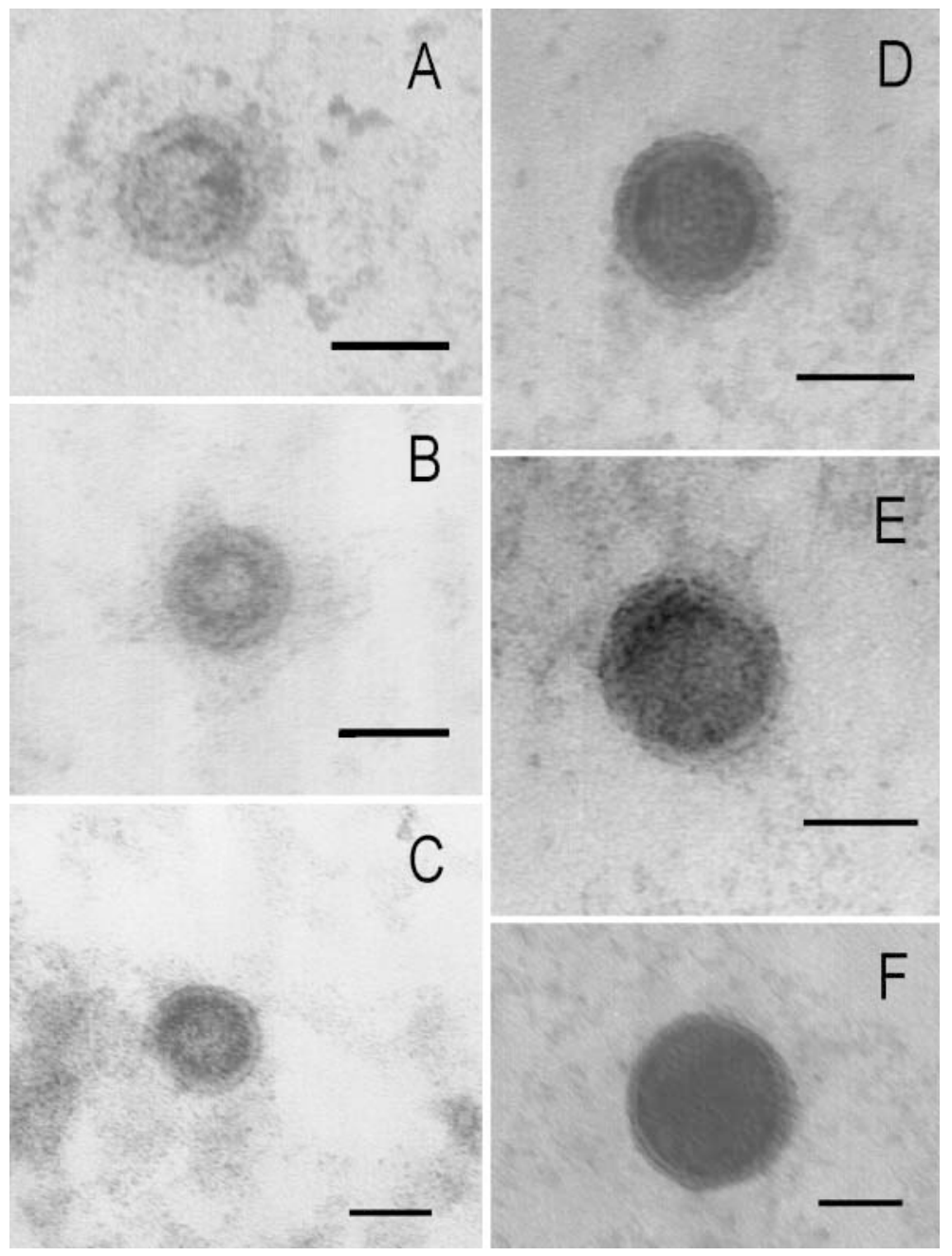

Fig. 4. Virus-like particles observed in lysate of Trichodesmium. (A) IMS101 culture; $(\mathrm{B}, \mathrm{C}) \mathrm{T}$. erythraeum from North Pacific; $(\mathrm{D}-\mathrm{F})$ T. thiebautii from North Pacific. Scale bars $=50 \mathrm{~nm}$

\section{Estimation of cyanophage abundance}

We measured titers of cyanophage capable of actively infecting the cultivated Trichodesmium sp. strain, with MPN between $6 \times 10^{2}$ and $1 \times 10^{4}$ viruses $\mathrm{ml}^{-1}$ $\left(\right.$ mean $=3.96 \times 10^{3}$ viruses $\left.\mathrm{ml}^{-1}\right)$. Negative control plates containing Trichodesmium spp. IMS101, but with no added seawater filtrate, were also grown and had no culture clearing, indicating that the absence of Trichodesmium spp. IMS101 in some wells was due indeed to interaction with filterable lytic agents. There was no clear trend in cyanophage vertical distribution with both highest and lowest cyanophage titers occurring in 2 surface water samples. MPN analysis was also conducted on the $0.2 \mu \mathrm{m}$ filtered lysate of a Trichodesmium sp. bloom in Tampa Bay; however no culture lysis was observed even at low dilutions, indicating that no cyanophage capable of infecting the culture were detectable in this decomposing bloom. It is important to note that the culture represents only a single strain of Trichodesmium spp., tentatively identified as T. erythraeum (Prufert-Bebout et al. 1993), and the MPN titers represent a minimum estimate of cyanophage abundance, because not all Trichodesmium-infecting cyanophage present may affect this strain Additionally, since IMS101 apparently contains a prophage (VLP produced when washed or treated with mitomycin C), it 


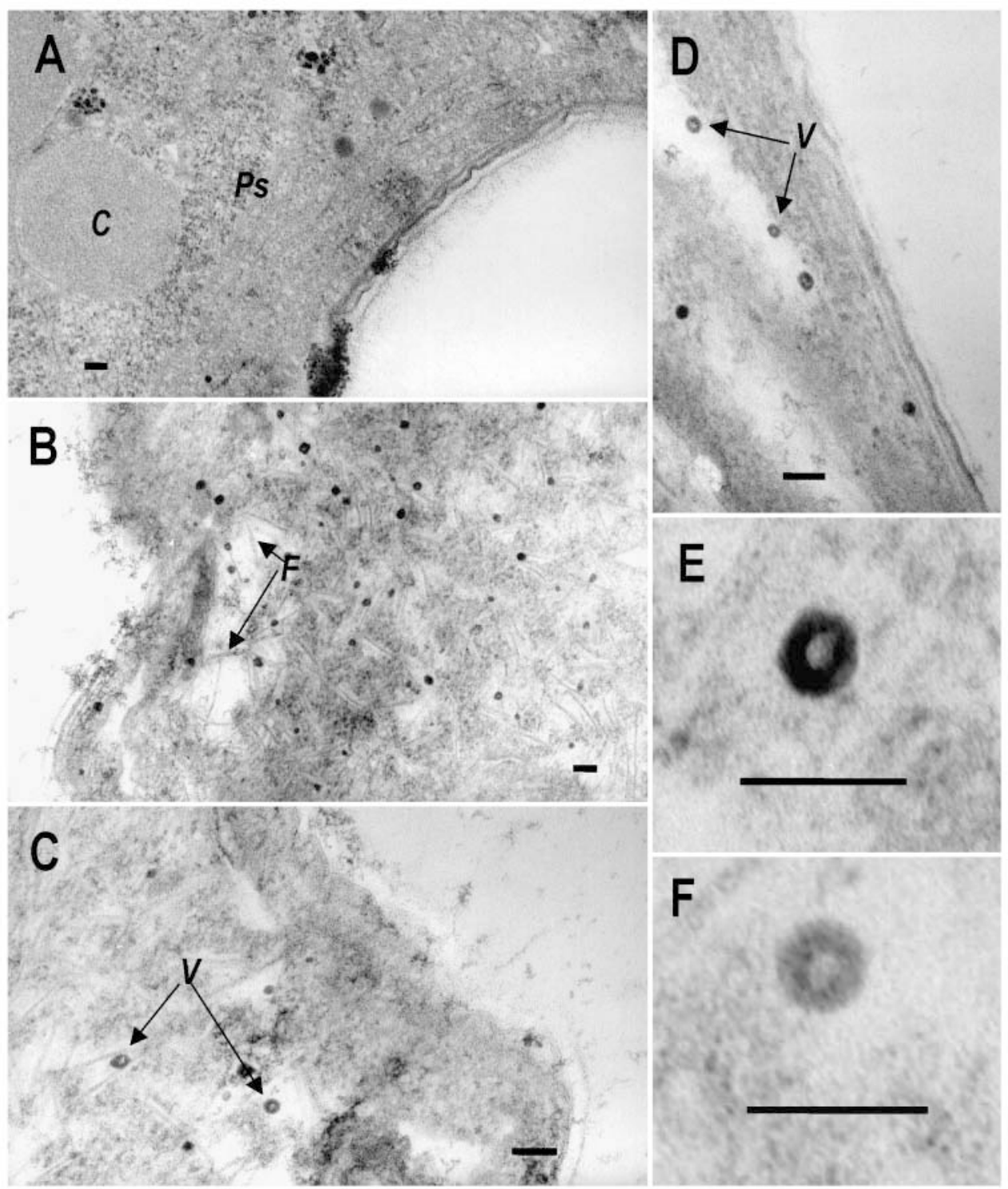

Fig. 5. TEM of thin-sectioned Trichodesmium IMS101 (A) with no treatment and (B-D) $24 \mathrm{~h}$ after treatment with mitomycin C. Untreated, but contained (for $24 \mathrm{~h}$ ) IMS 101 contained polysomes (Ps) and carboxysomes $(C)$ but no virus-like particles, while mitomycin $\mathrm{C}$ treated samples had no recognizable carboxysomes, and polysomes were distributed throughout the cells. A large number of virus-like particles $(V)$ and fiber-like inclusions $(F)$ were observed in the mitomycin $C$ treated cells. Virus-like particles $(\mathrm{E}-\mathrm{F})$ were approximately 26 to $40 \mathrm{~nm}$ wide and morphologically resembled particles in lysate. Scale bars $=50 \mathrm{~nm}$

may be homoimmune to closely related viruses (Ackermann \& DuBow 1979). This may be another source of underestimation of cyanophage abundance.

\section{Estimation of Trichodesmium mortality rates}

Our mortality estimates in natural samples are based upon a steady-state maintenance of observed cyanophage abundance, which could be from lysogeny, pseudolysogeny, carrier state, or successive lytic infection, since MPN-detected cyanophage could arise as a consequence of either process. VLP production rates and disappearance of most trichomes from freshly collected field populations are consistent with the possibility that a large number of cells contain prophage. The large VLP production in incubations is probably an artifact caused by handling or containment; however, this does not affect estimation of viral mortality because the mechanism of cyanophage production is not pertinent to our calculation. If all infective cyanophage observed by MPN arise as a result of Trichodesmium spp. lysis, then approximately 0.3 to $6.5 \%$ trichomes $\mathrm{d}^{-1}\left(\right.$ mean $\left.=1.65 \pm 1.00 \% \mathrm{~d}^{-1}\right)$ were lysed in 
Table 1. Estimated mortality of natural Trichodesmium spp. populations in the North Pacific Ocean in October 2002. Mortality of Trichodesmium was determined as described in the text using an average cyanophage titer of $3.69 \times 10^{3}$ $\mathrm{ml}^{-1}$, average decay rates shown here, ambient Trichodesmium spp. abundances, and the estimated trichome burst size (number of viruses per trichome). nd $=$ not determined

\begin{tabular}{|lccc|}
\hline Stn & $\begin{array}{c}\text { Trichome burst size } \\
\left(\text { virus } \times 10^{5} \text { trichome }^{-1}\right)\end{array}$ & $\begin{array}{c}\text { Virus decay rate } \\
\left(\% \mathrm{VLP} \mathrm{h}^{-1}\right)\end{array}$ & $\begin{array}{c}\text { Estimated mortality } \\
\left(\% \text { trichomes } \mathrm{d}^{-1}\right)\end{array}$ \\
\hline 3 & $0.38 \pm 0.03$ & nd & 1.68 \\
5 & $4.76 \pm 0.22$ & 0.8 & 0.26 \\
8 & $0.16 \pm 0.03$ & nd & 6.53 \\
10 & $1.05 \pm 0.19$ & 1.4 & 0.41 \\
13 & $0.70 \pm 0.04$ & nd & 0.69 \\
16 & $1.75 \pm 0.06$ & 1.2 & 0.32 \\
Avg. seawater & $1.47 \pm 0.68$ & 1.13 & 1.65 \\
IMS101 & $0.20 \pm 0.03$ & 4.4 & - \\
\hline
\end{tabular}

\section{CONCLUSION}

In the absence of significant grazing pressure, the fate of Trichodesmium has been somewhat of a mystery. The results presented here demonstrate that cyanophage infecting Trichodesmium spp. may cause significant mortality of natural populations and may contribute substantially to DON release into surrounding waters. We propose that these estimates of cell lysis represent the minimum amount of mortality that can be attributed to viral lysis because the MPN assay was conducted on only a single strain of Trichodesmium spp., and any additional

the surface waters (Table 1), which is consistent with calculated mortality rates derived from models of Trichodesmium sp. dynamics at the Bermuda Atlantic Time Series Site (2.1 to $2.4 \% \mathrm{~d}^{-1}$ ) (Hood et al. 2002) and in the equatorial Atlantic $\left(\sim 2.5 \% \mathrm{~d}^{-1}\right)$ (Hood et al. 2004).

The heterotrophic bacterial burst size used to correct for bacterial abundance is larger than the average burst size recorded for bacterioplankton (Wommack \& Colwell 2000), which range from 10 to 400 with a mean of 24 . We chose to use a larger burst size in our calculations, because bacteria observed in microscopy were larger than most bacterioplankton cells $(\sim 1 \mu \mathrm{m}$ long and often chain-forming rods), which presumably would result in larger numbers of viruses. Lower heterotrophic bacterial burst sizes would result in higher trichome burst sizes and consequently lower mortality rates of Trichodesmium from cyanophage MPN estimates. For example, if the burst size of heterotrophic bacteria is only 10 viruses cell ${ }^{-1}$, then the number of trichomes lysed by viruses would be 0.2 to $4.3 \%$.

Considering Trichodesmium spp. has a slow growth rate (culture $\mu \approx 0.2 \mathrm{~d}^{-1}$ (Prufert-Bebout et al. 1993) and field samples are thought to grow at approximately $0.1 \mathrm{~d}^{-1}$ (Capone et al. 1997), viral lysis may therefore release between 3 and $65 \%$ of Trichodesmium spp. production. Considering $\mathrm{N}_{2}$ fixation rates by Trichodesmium are on average approximately 43 pmol $\mathrm{N}$ trichome $\mathrm{d}^{-1} \mathrm{~d}^{-1}$ (Capone et al. 1997), viral lysis could release between 3 and $65 \%$ of fixed $\mathrm{N} \mathrm{d}^{-1}$, which is consistent with rates of DON release from trichomes in laboratory incubations (Glibert \& Bronk 1994). Since Trichodesmium fix from 100 to $300 \mu \mathrm{mol} \mathrm{N} \mathrm{m} \mathrm{N}^{-1}$ in the tropical North Pacific Ocean (reviewed in Capone et al. 1997), viral lysis may account for the release of 3 to $195 \mu \mathrm{mol} \mathrm{N} \mathrm{m}{ }^{-2}$ $\mathrm{d}^{-1}$, which represents a major mechanism by which newly fixed $\mathrm{N}$ enters the food web. phage not affecting this strain would add to the estimated virus production and thus increase the estimated mortality rate. Viral lysis of Trichodesmium thus represents a potentially large source of mortality in natural populations, and may be responsible for significant release of $\mathrm{N}$ into the marine food web.

Acknowledgements. We thank J. A. Sohm, J. A. Finzi, T. E. Gunderson and J. A. Burns for assistance with cultures; C. A. Heil for supplying the Tampa Bay sample; P. J. Morris and G. Toro for logistical support; and M. V. Brown, J. A. Steele and M. S. Schwalbach for helpful comments on the manuscript. We are grateful to A. Thompson at USC CEMMA for assistance with TEM; and the crew of the RV 'Kilo Moana'. This work was supported by NSF grants OCE-9981371 awarded to D.G.C., OCE-9981545 awarded to D.G.C., A. Michaels and A. Subramaniam, OCE-9981662 awarded to E.J.C. and OCE0241723 awarded to J.A.F.

\section{LITERATURE CITED}

Ackermann HW, DuBow MS (1979) Viruses of prokaryotes. CRC Press, Boca Raton, FL

Capone DG, Ferrier MD, Carpenter EJ (1994) Amino acid cycling in colonies of the planktonic marine cyanobacterium Trichodesmium thiebautii. Appl Environ Microbiol 60:3989-3995

Capone DG, Zehr JP, Paerl HW, Bergman B, Carpenter EJ (1997) Trichodesmium, a globally significant marine cyanobacterium. Science 276:1221-1229

Fuhrman JA (1999) Marine viruses and their biogeochemical and ecological effects. Nature 399:541-548

Fuhrman JA, Suttle CA (1993) Viruses in marine planktonic systems. Oceanography 6:51-63

Glibert PM, Bronk DA (1994) Release of dissolved organic nitrogen by marine diazotrophic cyanobacteria, Trichodesmium spp. Appl Environ Microbiol 60:3996-4000

Glibert PM, O'Neil JM (1999) Dissolved organic nitrogen release and amino oxidase activity by Trichodesmium spp. Bull Inst Oceanogr (Monaco) 19:265-272

Hawser SP, O'Neil JM, Roman MR, Codd GA (1992) Toxicity of blooms of the cyanobacterium Trichodesmium to zooplankton. J Appl Phycol 4:79-86 
Heldal M, Bratbak G (1991) Production and decay of viruses in aquatic environments. Mar Ecol Prog Ser 72:205-212

Hewson I, O'Neil JM, Dennison WC (2001) Virus-like particles associated with Lyngbya majuscula (Cyanophyta; Oscillatoriacea) bloom decline in Moreton Bay, Australia. Aquat Microb Ecol 25:1-10

Hood RR, Bates NR, Capone DG, Olson DB (2002) Modeling seasonal and interannual biogeochemical and $\mathrm{N}_{2}$-fixation cycles at BATS. Deep-Sea Res Part II 48:1609-1648

Hood RR, Coles VJ, Capone DG (2004) Modeling the distribution of Trichodesmium and nitrogen fixation in the Atlantic Ocean. J Geophys Res (in press)

Jiang SC, Paul JH (1994) Seasonal and diel abundance of viruses and occurrence of lysogeny/bacteriocinogeny in the marine environment. Mar Ecol Prog Ser 104:163-172

McDaniel L, Houchin LA, Williamson SJ, Paul JH (2002) Lysogeny in marine Synechococcus. Nature 415:496

Middelboe M, Lyck PG (2002) Regeneration of dissolved organic matter by viral lysis in marine microbial communities. Aquat Microb Ecol 27:187-194

Murray AG, Jackson GA (1992) Viral dynamics: a model of the effects of size, shape, motion and abundance of singlecelled planktonic organisms and other particles. Mar Ecol Prog Ser 89:103-116

Noble RT, Fuhrman JA (1997) Virus decay and its causes in coastal waters. Appl Environ Microbiol 63: 77-83

Noble RT, Fuhrman JA (1998) Use of SYBR Green I rapid epifluorescence counts of marine viruses and bacteria. Aquat Microb Ecol 14:113-118

Ohki K (1999) A possible role of temperate phage in the regulation of Trichodesmium biomass. Bull Inst Oceanogr (Monaco) 19:287-292

Ohki K, Fujita Y (1996) Occurrence of a temperate cyanophage lysogenizing the marine cyanophyte Phormidium persicinum. J Phycol 32:365-370

O'Neil JM, Roman MR (1994) Ingestion of the cyanobacterium Trichodesmium spp. by pelagic harpacticoid

Editorial responsibility: Curtis Suttle,

Vancouver, Canada copepods Macrosetella, Miracia and Oculosetella. Hydrobiologia 292/293:235-240

O'Neil JM, Metzler PM, Glibert PM (1996) Ingestion of ${ }^{15} \mathrm{~N}_{2}$ labelled Trichodesmium spp. and ammonia regeneration by the harpactacoid copepod Macrosetella gracilis. Mar Biol 125:89-96

Prufert-Bebout L, Paerl HW, Lassen C (1993) Growth, nitrogen fixation and spectral attenuation in cultivated Trichodesmium species. Appl Environ Microbiol 59: 1367-1375

Roman MR (1978) Ingestions of the blue-green alga Trichodesmium by the harpactacoid copepod, Macrosetella gracilis. Limnol Oceanogr 23:1245-1248

Sheridan CC, Steinberg DK, Kling GW (2002) The microbial and metazoan community associated with colonies of Trichodesmium spp.: a quantitative survey. J Plankton Res 24:913-922

Suttle CA (1994) The significance of viruses to mortality in aquatic microbial communities. Microb Ecol 28:237-243

Suttle CA (2000) Cyanophages and their role in the ecology of cyanobacteria. In: Whitton A, Potts $M$ (eds) The ecology of Cyanobacteria. Kluwer Academic, Amsterdam, p 563-589

Suttle CA, Chan AM (1993) Marine cyanophages infecting oceanic and coastal strains of Synechococcus: abundance, morphology, cross-infectivity and growth characteristics. Mar Ecol Prog Ser 92:99-109

Weinbauer MG, Suttle CA (1996) Potential significance of lysogeny to bacteriophage production and bacterial mortality in coastal waters of the Gulf of Mexico. Appl Environ Microbiol 62:4374-4380

Wolfe FL, Berman-Frank I, Haramaty L, Falkowski PG (2003) The metallic shield of Trichodesmium: fighting oxidative damage. American Society for Limnology and Oceanography, Salt Lake City, UT

Wommack KE, Colwell RR (2000) Virioplankton: viruses in aquatic ecosystems. Microbiol Mol Biol Rev 64:69-114

Submitted: March 25, 2004; Accepted: April 13, 2004

Proofs received from author(s): June 3, 2004 